\title{
The Role of Judicial Commission on Supervision of Judge's Crime in Indonesia
}

\begin{abstract}
Ahmad Firmanto Prasedyomukti ${ }^{1}$ and Rakhmat Bowo Suharto ${ }^{2}$
Abstract. This booklet is designed to examine the effectiveness of the Judicial Commission's role in the supervision of judge's crime in Indonesia, as well as existence. Based on the discussion, we can conclude: 1) The role of the Judicial Commission in the framework of the supervision of judge's crime has not been effective, due to the legal existence of the Judicial Commission recognized but on a practical level does not have the authority to impose administrative punishment on their own, the Judicial Commission had no authority investigations against the judge found to have violated the rules of the criminal. 2) Need for reconstruction of the existence of the Judicial Commission under the supervision of judge's crime offense, so there is a balance between the authority of the Judicial Commission and the follow-up comprehensively.

Keywords: Judicial Commission; Supervision; Judge.
\end{abstract}

\section{Introduction}

According to Act No. 48 Of 2009 regarding Judicial Power, Article 1 (1) stated that the judicial power is the power of a sovereign state to conduct judiciary to uphold law and justice based on Pancasila and the Constitution of the Republic of Indonesia Of 1945 for the sake of the implementation of the State law of the Republic of Indonesia. In this case, judges are state officials who perform judicial authority stipulated in the Act. ${ }^{3}$ As state officials who perform judicial power, the judge must have integrity and a personality that is not dishonorable, honest, fair, professional and experienced in the field of law. In carrying out its duties and functions, judges shall maintain the independence of the judiciary. With regard to the hope and effort to get a good judge, who has the integrity and the professional is required commitments related institutions that have the authority to recruit and select judges, namely by promoting the principles of transparency, participation, accountability, right man on the right place and objectively. ${ }^{4}$

Integrity can be meant with a trait, which shows the quality of the state of complete unity so that it has the potential and ability that exudes authority and honesty. ${ }^{5}$ In view of the Judicial Commission, the principles of integrity as attitude and personality intact, authoritative, honest and unwavering. In the context of judicial office as state officials charged with enforcing law and justice, the integrity of the elements of the judge candidates can be obtained through a rigorous recruitment and selection and good. However, the integrity that must be nurtured and developed in a sustainable manner

\footnotetext{
${ }^{1}$ Student of Masters (S2) of Law Faculty of Law Unissula Semarang e-mail : firmanto_afs@yahoo.com

2 Lecturer of Faculty of Law UNISSULA Semarang

${ }^{3}$ Article 31 of Act No. 4 of 2004 on Judicial Power.

${ }^{4}$ Wahyu Wiriadinata, 2014, Asy-Syir'ah Jurnal Ilmu Syari'ah dan Hukum, Vol. 48, No. 2, Desember, p. 516.

${ }^{5}$ Kamus Umum Bahasa Indonesia $3^{\text {rd }}$ Edition, (Jakarta: Balai Pustaka, 1999), p. 347.
} 
through education and training. If a judge with integrity, by itself have the potential and capability that will eventually give birth to the dignity and honesty. ${ }^{6}$

On the basis of that background appears a need for independent agency established and authorized by the Constitution to conduct oversight of the judges in order to remain in compliance with the code of conduct of judges and legal requirements. Such entities were then given the name of the Judicial Commission. Based on Article $24 \mathrm{~B}$ of paragraph (1) is: an independent judicial commission is authorized to propose the appointment of the Chief of Justice and the other having authority in order to preserve and uphold the honor, dignity and conducts of judges. The presence of the Judicial Commission (KY) are extremely vital in the effort to push for judicial reform, including aspects related to maintaining the honor, dignity, dignity, ethics and behavior of judges in Indonesia.

Judicial Commission who was born in the reform era III amendment to the Constitution of 1945 in 2001 in conjunction with the Regional Representative Council and the Constitutional Court, although the Yudisisal Commission is a new institution, but its presence has a very strong legal justification for strictly regulated in Law Constitution of the Republic of Indonesia in 1945 and granted by the constitution. ${ }^{7}$

In practice, the Judicial Commission is an institution that helps in performing the tasks of judicial power, but as a state institution that becomes an external supervisor. The Judicial Commission is actually an independent state agencies such as the explicitly mentioned in Article 24B paragraph (1). ${ }^{8}$ Further stated that the Judicial Commission is not an institution of judicial power, but the duty of state institutions related to the competent of judicial authority propose the appointment of the Chief Justice and other authorities in order to preserve and uphold the honor, dignity and conducts of judges. Thus, the judicial commission is a state institution established by the constitution to carry out external supervision of the judge.

One form of the development of the principle of the integrity of judges are judges behave beyond reproach and avoid giving the gift of giving local governments even though they do not affect judicial duties. But in practice, there are some judges who indicated the ban violates the criminal cases related to bribery in order to ease the suspect. In this case, the Judicial Commission has the authority and role in overseeing the criminal offense committed by the judge, who was accompanied by the police as the case investigator.

Based on the description, the subject matter of this article is how the role of the Judicial Commission under the supervision of a judge's crime offense in Indonesia.

\section{Discussion}

\subsection{Theory Judge's Control}

In the context of the rule of law, surveillance is an essential ingredient in creating a clean government, so anyone state officials may not refuse to watch, seeing nothing

\footnotetext{
${ }^{6}$ Ibid., p.517.

${ }^{7}$ H. Zainal Rifin, Fungsi Komisi Yudisial dalam Reformasi Peradilan Sesudah dan Sebelum Putusan Mahkamah Konstitusi, Makalah, Jakarta, 2006, p. 2

${ }^{8}$ Moh. Mahfud MD, Perdebatan Hukum Tata Negara (Jakarta: LP3ES, 2007), p. 117
} 
else to conduct surveillance controls aimed at preventing the absolutism of power, authoritarianism and abuse of authority. ${ }^{9}$

According to Paulus Effendi Lotulung, supervision (control) is an attempt to avoid the occurrence of mistakes, either intentionally or unintentionally as preventive measures, or also to correct the error when it occurs as a repressive effort. ${ }^{10}$ Muchan argued that the surveillance is to assess the activities of a de facto implementation of the tasks, while the objective of supervision is confined to the match whether the activities carried out in accordance with the benchmarks previously set. ${ }^{11}$ While Manan view control as a function and the right, so commonly known as control or right of control functions, the control contains dimensional inspection and control, supervision related to the direction (directife). ${ }^{12}$

In order to support the improvement of the human resources in reforming the law is necessary to supervise. According to the classification Fachrudin surveillance, including: ${ }^{13}$

- Supervision in terms of institutional control and carry out control can be classified as: 1) internal control. 2) external control.

- Supervision by their nature can be distinguished as follows:

- Preventive supervision of a supervisory nature in order to prevent irregularities.

- Supervision repressive nature or restore correcting erroneous actions.

- Supervision is seen from the aspect of being watched can be classified into:

- Supervision in terms of law (legality).

- Supervision in terms of expediency (oppurtunity), monitoring is intended to assess in terms of its usefulness (doelmatigheid).

\subsection{Judicial Commission}

The Judicial Commission in Article 1 of Act No. 18 of 2011 on the Amendment of Act No. 22 Of 2004 concerning Judicial Commission, the Judicial Commission is the state agency as defined in the Constitution of the Republic of Indonesia Of 1945. Third Amendment 1945 introduced a new state institution as an institution helper (auxiliary institusion) in a clump of judicial authority that the Judicial Commission regulated in article $24 \mathrm{~B}$ of the Constitution as follows: ${ }^{14}$

a. Independent judicial commission is authorized to propose the appointment of the Chief Justice and the other having authority in order to preserve and uphold the honor, dignity, dignity, as well as the behavior of judges.

b. Judicial Commission members shall have knowledge and experience in the field of law and the integrity and personality that is not dishonorable.

\footnotetext{
${ }^{9}$ Yohanes Usfunan, Bunga Rampai Refleksi Satu Tahun Komisi Yudisial, Komisi Yudisial, Jakarta, p. 207

${ }^{10}$ Paulus Effendi Lotulung, Beberapa Sistem tentang Kontrol Segi Hukum terhadap Pemerintah, Citra Aditya Bakti, Bandung, 1993, p. Xvixvii.

${ }^{11}$ Muchsan, Sistem Pengawasan terhadap Perbuatan Aparat Pemerintah dan Peradilan Tata Usaha Negara, Liberty, Yogyakarta, 1992, p. 37

${ }^{12}$ Bagir Manan, Menyongsong Fajar Otonomi Daerah, Yogyakarta: pusat Studi Fakultas Hukum UII, 2001, p. 20

${ }^{13}$ W. Riawan Tjandra, Hukum Keuangan Negara, PT. Grasindo, Jakarta, 2006, p. 133

${ }^{14}$ Moh. Mahfud MD, Perdebatan Hukum Tata Negara (Jakarta: LP3ES, 2007), p. 117.
} 
c. Judicial Commission members are appointed and dismissed by the President with the approval of the House of Representatives.

d. The composition, status and membership of the Judicial Commission shall be regulated by Law.

Judicial Commission, which in this case as an institution that played a role in the nomination of the power Judiciary against the appointment of judges to the supervision of judges has undergone and passed dynamics since the stand up until today. Since the end of 2005 until at least mid-2006, the people of Indonesia, especially the legal community, manyaksikan scene of conflict between the two state institutions namely the Supreme Court (MA) and the Judicial Commission (KY). Judicial Commission as a new state agency then gets the spotlight, both positive and negative. $^{15}$

Regarding the position of the Judicial Commission, there are several perspectives. Some claimed that the Judicial Commission are state institutions for the Judicial Commission regulated and established by the Constitution NRI 1945. Then there is the claim that state auxiliary organ of the Judicial Commission (auxiliary state agency) as an institution that supports the institution of power of judges, the Judicial Commission shall be responsible to public through Parliament, by issuing annual reports and open access to complete and accurate information. ${ }^{16}$

In the framework of the honor, dignity and conducts of judges, KY according to Article 20 of Act No. 18 of 2011 has the task of: 1) monitoring and supervision of the conduct of judges. 2) receive reports from the public relating to violations of the code of conduct and / or guidelines for the conduct of judges. 3) verification, clarification, and investigate reports of alleged violations of the code of conduct and / or guidelines for the conduct of judges. 4) decide whether or report alleged violations of the code of conduct and / or guidelines for the conduct of judges. 5) take legal action and / or other measures against those individuals, groups, or legal entities degrading the honor and dignity of judges.

In addition to the provisions contained in Act No. 18 of 2011 as mentioned earlier, the Judicial Commission explicitly stated as a supervisory agency external behavior of judges in Act No. 49 Of 2009 on Judicial umun, Act No. 50 of 2009 on the Religious Courts, and Act No. 51 of 2009 on State Administrative Court authorizes KY to:

- Receive and follow up on complaints from the public and / or information on the alleged violation of the Code and / or the Code of Conduct of Judges,

- Examine and decide upon any alleged violation of the Code and / or the Code of Conduct of Judges,

- Can attend court proceedings, $d$. Receive and follow up complaints of the Supreme Court on the alleged violation of the Code and / or the Code of Conduct of Judges,

- Verification of the complaint,

- Request information or data to the Supreme Court and / or the courts,

- To call and ask for information from the judge suspected of violating the Code of Conduct and / or the Code of Conduct of Judges for inspection, and

\footnotetext{
${ }^{15}$ Moh. Mahfud MD, 2013, Op.Cit, p. 111

${ }^{16}$ Ibid.
} 
- Assign a decision based on the results of the examination.

KY accordance with Article 13 of Act No. 18 Of 2011 has four authorized namely: 1) propose the appointment of Supreme Court judges and ad hoc judges in the Supreme Court to Parliament for approval, 2) maintaining the honor, dignity and conducts of judges, 3) set code of Conduct and / or the code of Conduct of Judges together with MA, and 4) to maintain and enforce the implementation of the code of Conduct and / or the code of Conduct of Judges.

Article 19 A of Act No. 18 of 2011 states that in order to preserve and uphold the honor, dignity, and behavior of judges, KY guided by the Code of Conduct and / or the Code of Conduct of Judges predetermined KY and MA. The Judicial Commission (KY) established by Act No. 22 of 2004 concerning judicial commission is a state institution that by Article 24 of the 1945 Constitution mandated B has some authority, namely: ${ }^{17}$

- Propose the appointment of Supreme Court justices.

- Maintaining the honor, dignity generous nature, as well as the behavior of judges.

Article 24 B of paragraph (1) is set two things, first is the nature of the institutional KY independent, and the second is for the authorities of KY. Self-reliance can be given the meanings that these institutions can not and should not be interfered with or interfered with by any other authority or other parties. As a consequence of the independence of the positions $\mathrm{KY}$ institutions are not under any other state institution or being in the structure of other state institutions, including state agencies judicial power executor of which consists of judges who becomes the object of his power.

Although based Article 13 of Act No. 18 of 2011 KY has four major powers, but in practice obstacles which independently could not provide law enforcement in the judge. So the role of the Judicial Commission in the framework of the supervision of judges has not been effective, is because although legally recognized the existence of the Judicial Commission, but on a practical level does not have the authority to impose administrative punishment independently. In addition, the Judicial Commission also does not have the authority to conduct investigations against judges found to have violated the rules of the criminal.

\subsection{Theory of Duties and Authority of Judge}

According Syar'a (Islamic Law), judges are persons who appointed by the head of state to be a judge in the settling of lawsuit, a dispute-divergence in the field of civil law because the authorities themselves can not complete its job. ${ }^{18}$ According to the laws of the Republic of Indonesia number 48 of 2009 on Judicial Power that is a judge is a judge on the Supreme Court and judges at judicial bodies underneath it in the public courts, religious courts, military courts, administrative courts, and judges at a special court swithin the judicial environment. ${ }^{19}$

Article 5 of Act No. 48 of 2009 on the judicial authorities determine: (1) The judges and constitutional judges shall explore, and understand the legal values and sense of justice in society. (2) The judges and constitutional judges must have integrity and a

\footnotetext{
${ }^{17}$ See Act No. 22 of 2004

${ }^{18}$ Muhammad Salam Madkur, Peradilan Dalam Islam, (Surabaya: PT. Bina Ilmu 1993), p. 29

${ }^{19}$ Act No. 48 of 2009 on Judicial Power
} 
personality that is not dishonorable, honest, fair, professional, and experienced in the field of law. (3) The judges and constitutional judges must comply with codes of conduct and guidelines for the behavior of judges. ${ }^{20}$

Under the provisions of Article 17 of Act No. 48 of 2009 on the judicial authorities explained that the judge has a duty, as follows: ${ }^{21}$

- Parties have the right to be tried reneges against judges who hear his case.

- Right of refusal referred to in paragraph (1) is a person's right to be tried to file a complaint accompanied by reasons against a judge who tried his case.

- A judge must resign from the trial if bound related by blood or marriage to the third degree, or husband or wife relationship despite having been divorced, with the chairman, one of the member judges, prosecutors, advocates, or clerks.

- Chairman of the panel, panel members, prosecutors or clerks must resign from the trial if bound related by blood or marriage to the third degree, or husband or wife relationship despite having been divorced by the parties prosecuted or advocate.

- A judge or court clerk shall resign from the trial if he has a direct or indirect interest in the case being examined, either on his own or at the request of litigants.

- In case of any violation of the provisions referred to in paragraph (5), the ruling declared invalid and against the judge or clerk of the concerned subject to administrative sanctions or convicted in accordance with the provisions of laws and regulations.

- Case referred to in paragraph (5) and (6) is checked back in with a different composition of the panel of judges.

Independence, freedom or independence of the judicial power is absolutely necessary and fundamental to the country based on the state system of legal and democratic state. If the judicial authority in the country had been under the influence of other powers it can be ascertained that the country does not uphold the principles of rule of law and democracy. ${ }^{22}$

According to Bagir Manan, there is some substance in the independent judicial power, is as follows: $:^{23}$ a) The independent judicial power is the power to conduct judiciary or judicial function which includes the power to examine and decide a case or dispute and make a determination rule of law. b) The independent judicial power is intended to guarantee the independence of judges from various worries or fear as a result of a judgment or a decree law. c) The independent judicial power aims to ensure judges act objectively, honestly and impartially. d) The independent Judicial Power shall be done solely through the efforts of law, both general remedies and extraordinary legal remedy by judicial authorities and in lingkingan own. e) The independent judicial power to prohibit all forms of interference from outside powers of judicial power.

Franken, a legal expert from the Netherlands, said that the independence of the judicial power can be divided into four forms, namely: ${ }^{24}$

- The independence of the constitutional (constitusionele onafhankelijk-kheid).

\footnotetext{
${ }^{20}$ See Article 5 of Act No. 48 of 2009 on Judicial Power.

${ }^{21}$ See Article 17 of Act No. 48 of 2009 on Judicial Power.

22 Imam Anshori Saleh, Konsep Pengawasan Kehakiman, Setara Press, Malang, 2014, p.121

${ }^{23}$ Ibid., p. 122.

${ }^{24}$ Ibid.
} 
- Functional independence (zakleijke of functionele onafhankelijk-kheid)

- Personal independence of the judge (persoonlijke of rechtspositionele onafhankelijkkheid), and

- Independence of real practical (praktische of feitelijk onafhankelijkkheid).

Based on the independence of the judicial power, the judge must follow the development of public knowledge that can be read or seen through the media. Judges should not be influenced by a variety of news and then take away the words of media without thinking about it. Judges should also be able to filter the pressures of society to consider and critically examined with the existing legal provisions. Judges must know how far can apply to the social norms in society. ${ }^{25}$

Granting freedom to the judicial authority in carrying out justice indeed is appropriate, because the act is an act noble judge to deliver a verdict on a case solely be based on truth, honesty and fairness. Should be kept away from pressure or influence from any party, whether individual, society, let a government authority which usually has a strong network and wide. ${ }^{26}$

\section{Closing}

\subsection{Conclution}

Based on these discussions, it can be concluded that the role of the Judicial Commission in the framework of the supervision of judges has not been effective, is because although legally recognized the existence of the Judicial Commission, but on a practical level does not have the authority to impose administrative punishment independently. In addition Judicial Commission also does not have the authority to conduct investigations against judges found to have violated the rules of the criminal.

\subsection{Suggestion}

Need for reconstruction of the existence of the Judicial Commission under the supervision of a judge's crime offense, so there is a balance between the authority of the Judicial Commission and the follow-up comprehensively.

\section{Bibliography}

[1] Act No. 4 of 2004 on Judicial Power.

[2] Act No. 48 of 2009 on Judicial power.

[3] Bagir Manan, 2001, Menyongsong Fajar Otonomi Daerah, Pusat Studi Fakultas Hukum UII, Yogyakarta.

[4] Imam Anshori Saleh, 2014, Konsep Pengawasan Kehakiman, Setara Press, Malang.

[5] Kamus Umum Bahasa Indonesia $3^{\text {th }}$ edition, 1999, Balai Pustaka, Jakarta.

[6] Moh. Mahfud MD, 2007, Perdebatan Hukum Tata Negara, LP3ES, Jakarta.

[7] Muchsan, 1992, Sistem Pengawasan terhadap Perbuatan Aparat Pemerintah dan Peradilan Tata Usaha Negara, Liberty, Yogyakarta.

[8] Muhammad Salam Madkur, 1993, Peradilan Dalam Islam, Surabaya: Bina Ilmu.

\footnotetext{
${ }^{25}$ Ibid., p. 124.

${ }^{26}$ K Wantjik Saleh, Kehakiman dan Keadilan, Ghalia Indonesia, Jakarta, 1977, p. 17
} 
[9] Paulus Effendi Lotulung, 1993, Beberapa Sistem tentang Kontrol Segi Hukum terhadap Pemerintah, Citra Aditya Bakti, Bandung.

[10] Riawan Tjandra, 2006, Hukum Keuangan Negara, Grasindo, Jakarta.

[11] Wahyu Wiriadinata, 2014, Asy-Syir' ah Jurnal IImu Syari' ah dan Hukum, Vol. 48, No. 2, Desember.

[12] Wantjik Saleh, 1997, Kehakiman dan Keadilan, Ghalia Indonesia, Jakarta.

[13] Yohanes Usfunan, 2007, Komisi Yudisial, Bunga Rampai Refleksi Satu Tahun Komisi Yudisial, Komisi Yudisial RI, Jakarta.

[14] Zainal Rifin, 2006, Fungsi Komisi Yudisial dalam Reformasi Peradilan Sesudah dan Sebelum Putusan Mahkamah Konstitusi (Makalah), Jakarta. 